\title{
Fridtjof Nansen: Neuro-anatomical Discoveries, Arctic Explorations, and Humanitarian Deeds
}

\author{
Abraham Ohry, M.D. ${ }^{1}$ and Karin Ohry-Kossoy, M.A. \\ ${ }^{1}$ Neurological Rehabilitation Department, Sheba Medical Center, Tel Hashomer, \\ Israel
}

'Man wants to know, and when he ceases to do so, he is no longer a man'

F. Nansen

The IMSOP Meeting took place in Oslo on the 125th anniversary of Nansen's birth. Apart from his Arctic explorations, his political and humanitarian activities, he first pointed out that the posterior root fibres divide on entering the spinal cord into ascending and descending branches. This article is dedicated to the memory of a great Norwegian.

The 1986 IMSOP Meeting in Oslo took place at the time of the 125th anniversary of the birth of Fridtjof Nansen, one of Norway's most famous sons. He was an extremely gifted man with lofty ideals who left an enduring mark in all the fields in which he was active. Our own particular interest in him, however, concentrates on his neuro-anatomical discoveries (Christensen, 1961; Vogt, 1961).

Nansen was born in Norway in 1861. His family was of distinguished Danish origin. The orientations of his adult life were already clearly apparent during his childhood: at school he excelled in the sciences and in drawing, but also spent much time outdoors, skiing and exploring nature. In 1880 Nansen became a zoology student at the University of Christiania in Oslo, which enabled him to combine his interest in science with his love for outdoor life. During his freshman year he took the advice of his teacher, Prof. Robert Collett, and joined his first Arctic expedition, a seal-hunting trip from which he brought outstanding scientific observations illustrated with his own drawings. (Nansen, 1921, 1897; Berman 1899).

When he returned from that journey, the 21-year-old student was made curator at the Bergen Museum of Zoology, where the neuro-anatomy of the worms

Correspondence to:

A. Ohry, M.D., Neurological Rehabilitation Department, Sheba Medical Center, Tel Hashomer, 52621 , Israel. 
PARAPLEGIA
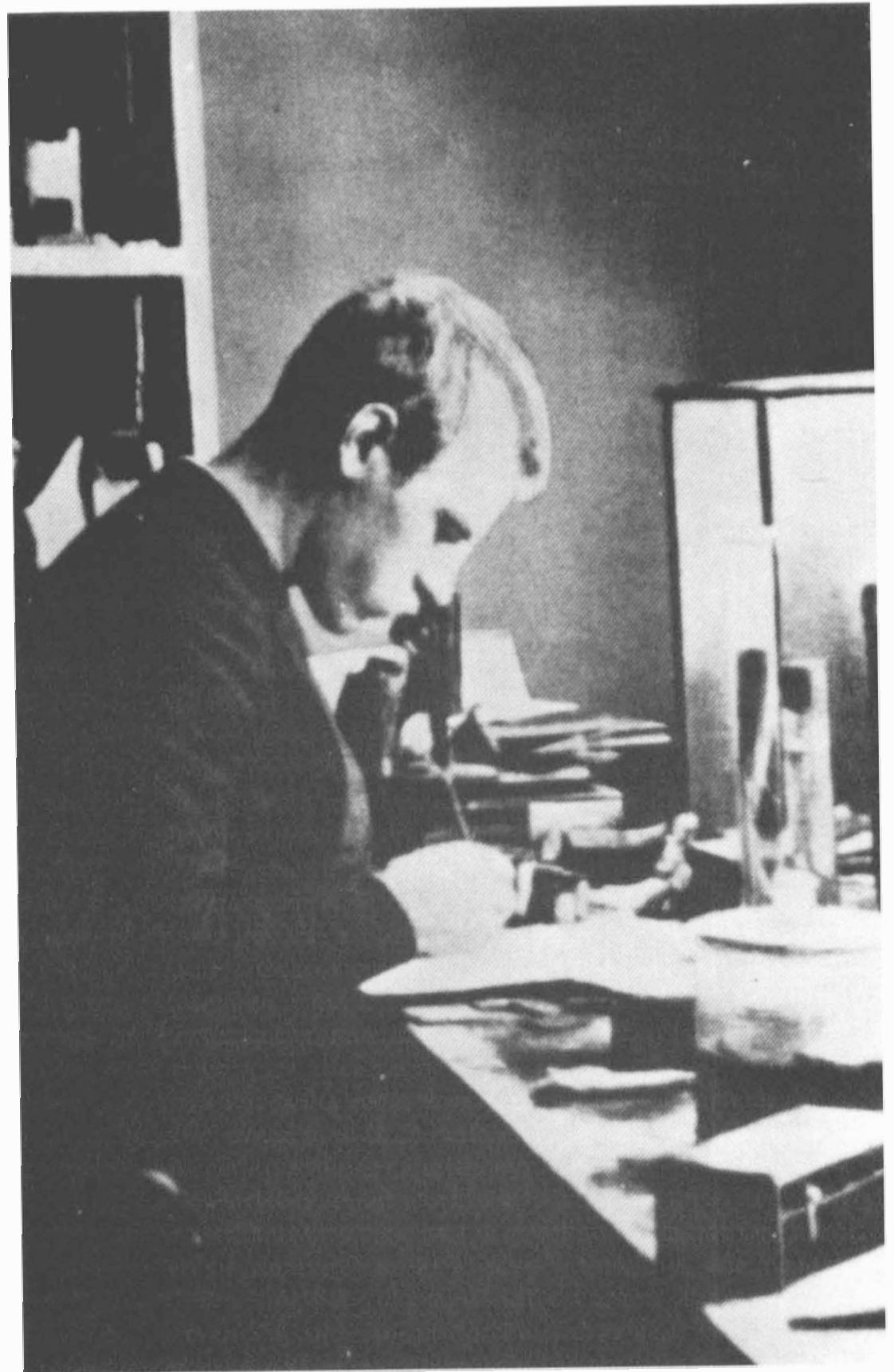

Figure 1 


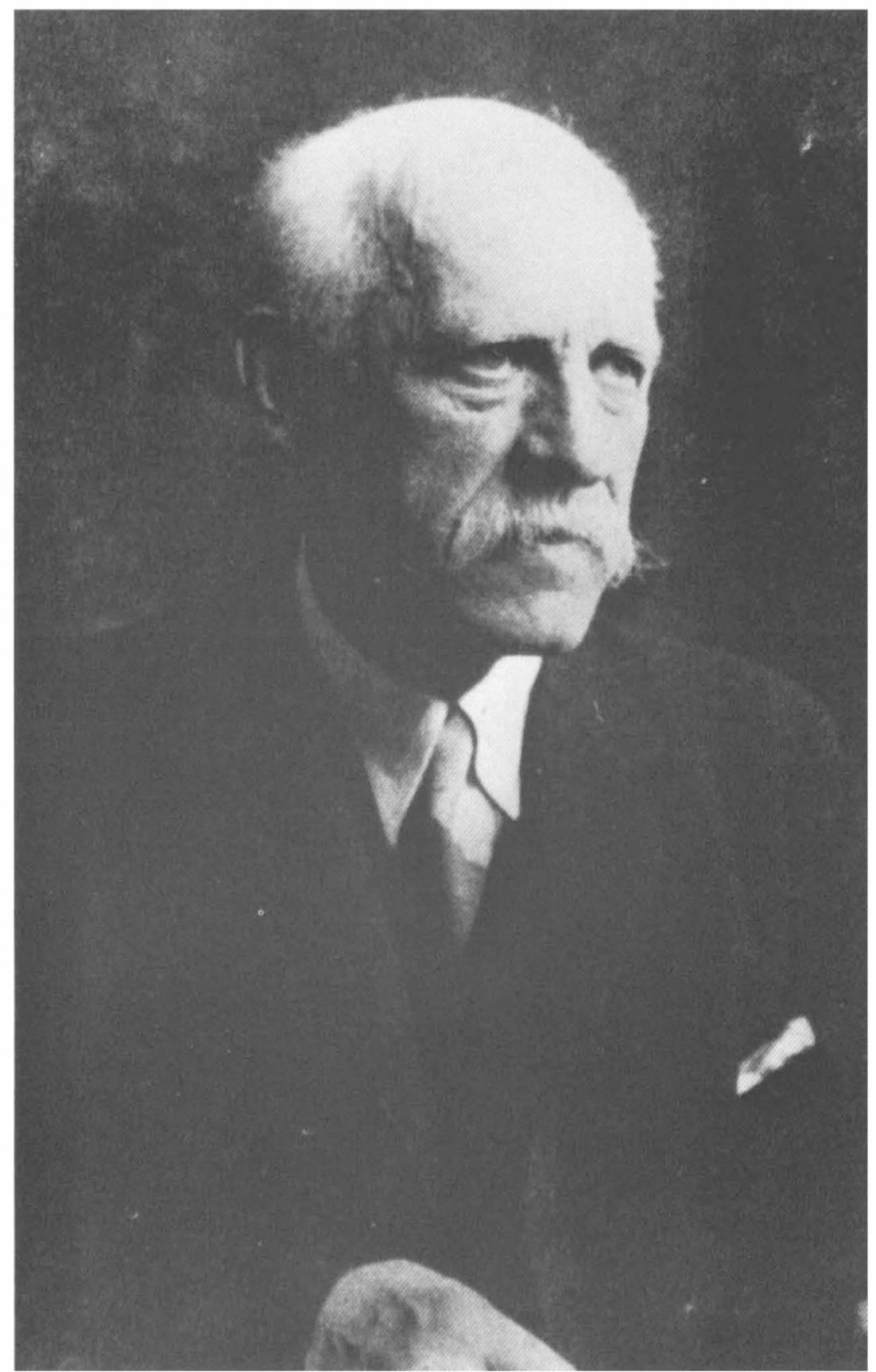

Figure 2 
called Myzostomae and Myxine glutinosa absorbed his attention. As Nansen later said: 'For 6 years I lived in a microscope' (Wyke, 1962) (Fig. 1). At the time the Director of the Bergen Museum was D.C. Danielssen, famous for his research on the pathology of leprosy. Another well known scientist then worked with Nansen, A. Hansen, who had isolated the leprosy bacillus. Microscopy was the latest technical innovation, and Camillo Golgi's silver impregnation of nerve tissue was also of recent origin. 'Histologists,' writes Wyke, were able 'for the first time to study the morphology of nerve cells and to trace their connections within the central nervous system.'

Danielssen sent Nansen to Europe for 1 year to gain more experience and to study new techniques. While in Italy Nansen worked with Golgi and learned his silver impregnation technique. Back in Bergen, 'applying the Golgi techniques to the nervous system of Myxine glutinosa, Nansen made numerous histological studies of the origin of the dorsal root fibres from the cells in the dorsal root ganglia, and traced their central branches into and within the spinal cord. As a result, in his Ph.D. thesis (Nansen, 1886) he was the first to describe the fact that each dorsal root fibre, on entering the spinal cord, bifurcates in a $T$-shaped fashion into ascending and descending branches that run intersegmentally through the neuraxis ('Nansen's fibres'), giving off collateral segmental branches to the cells in the spinal grey matter throughout their longitudinal course. (Wyke, 1962).

While preparing to defend this thesis Nansen was also getting ready to cross Greenland on skis, an incredibly dangerous premiere. A story went round saying the professors had decided to be very generous with the young man, since the new Ph.D. would not be coming back from the icy desert. But this was just a joke. Nansen's discovery was soon confirmed by Ramon y Cajal, used and referred to by Sherrington, hailed by Retzius, Déjerine and others.

After a year in Greenland Nansen returned a national hero. Back in his lab, writes Wyke, 'Nansen described-again for the first time-the mixture of bipolar and unipolar neurones ("cells of Nansen")' in lower vertebrates. This paper was published in 1895, while Nansen was away up North on his historic three-year journey with his ship 'Fram', proving that an Arctic Ocean current flowed across the Polar basin.

Nansen became Professor of Zoology, then of Oceanography. He helped Norway secure its independence from Sweden and represented his country at the League of Nations (Nansen 1928). In the wake of the First World War he organised the repatriation of 500000 prisoners of war, created the Nansen passport for stateless persons and supervised relief operations involving millions of people. His tireless devotion to suffering mankind was also rooted in personal tragedy: one of his five children had cerebral palsy and died at the age of ten. Nansen received the Nobel Peace Prize in 1922 and died in 1930, one of the greatest men of our century (Fig. 2).

\section{References}

Berman S 1899 F Nansen and his voyages. Petrokov, Russia, translated into Hebrew, Tushia Ed, 3 vols. 
Christensen AR 1961 F Nansen-a life in the service of science and humanity. High Commisioner for Refugees and the Norwegian Refugee Council and the Cultural Office of the Norwegian Ministry of Foreign Affairs.

NANSEN F 1921 Eskimoleben. Globus Verlag, Berlin.

NANSEN F 1897 In Nacht und Eis. FA Brockhaus, Leipzig (2 vols).

Nansen F 1928 L'Arménie et le Proche Orient. Imprimerie Massis, Paris.

NANSEN F 1886 The structure and combination of the histological elements of the central nervous system. Bergen Museum Aarsberetning p. 29-214 (appeared in Morton LT (1970), A Medical Bibliography-Garrison-Morton, 32nd Edition, A Grafton Book, Andre Deutch, p. 170).

Vogt P 1961 F Nansen, explorer, scientist, humanitarian. Dryers Forlog, Oslo.

WyKE B 1962 Fridtjof Nansen, G.C.V.O. D.Sc., D.C.L., Ph.D., (1861-1930). A note on his contributions to Neurology on the Occasion of the Centenary of his Birth. Annals of the Royal College of Surgery England 30:243-252. 